\title{
RNA-seq analysis identifies an intricate regulatory network controlling cluster root development in white lupin
}

\author{
David Secco ${ }^{1}$, Huixia Shou ${ }^{2,3}$, James Whelan ${ }^{3,4}$ and Oliver Berkowitz ${ }^{1,5^{*}}$
}

\begin{abstract}
Background: Highly adapted plant species are able to alter their root architecture to improve nutrient uptake and thrive in environments with limited nutrient supply. Cluster roots (CRs) are specialised structures of dense lateral roots formed by several plant species for the effective mining of nutrient rich soil patches through a combination of increased surface area and exudation of carboxylates. White lupin is becoming a model-species allowing for the discovery of gene networks involved in CR development. A greater understanding of the underlying molecular mechanisms driving these developmental processes is important for the generation of smarter plants for a world with diminishing resources to improve food security.

Results: RNA-seq analyses for three developmental stages of the CR formed under phosphorus-limited conditions and two of non-cluster roots have been performed for white lupin. In total 133,045,174 high-quality paired-end reads were used for a de novo assembly of the root transcriptome and merged with LAGI01 (Lupinus albus gene index) to generate an improved LAGI02 with 65,097 functionally annotated contigs. This was followed by comparative gene expression analysis. We show marked differences in the transcriptional response across the various cluster root stages to adjust to phosphate limitation by increasing uptake capacity and adjusting metabolic pathways. Several transcription factors such as PLT, SCR, PHB, PHV or AUX/IAA with a known role in the control of meristem activity and developmental processes show an increased expression in the tip of the CR. Genes involved in hormonal responses (PIN, LAX, YUC) and cell cycle control (CYCA/B, CDK) are also differentially expressed. In addition, we identify primary transcripts of miRNAs with established function in the root meristem.
\end{abstract}

Conclusions: Our gene expression analysis shows an intricate network of transcription factors and plant hormones controlling CR initiation and formation. In addition, functional differences between the different CR developmental stages in the acclimation to phosphorus starvation have been identified.

Keywords: Cluster root, White lupin, Root development, Phosphate, RNA-seq, de novo transcriptome

\section{Background}

Phosphorus ( $\mathrm{P})$ is often one of the most limiting plant nutrients in soils leading to impeded plant growth and development. Although inorganic phosphate $(\mathrm{Pi})$ is often abundant in soils, availability to the plant is limited by slow diffusion and fixation, e.g. as aluminum or iron oxide complexes [1]. Therefore fertilisation with Pi derived from

\footnotetext{
*Correspondence: oliver.berkowitz@uwa.edu.au

${ }^{1}$ Australian Research Council Centre of Excellence in Plant Energy Biology,

University of Western Australia, Crawley, WA 6009, Australia

${ }^{5}$ School of Plant Biology, University of Western Australia, Crawley, WA 6009,

Australia

Full list of author information is available at the end of the article
}

mined rock phosphate is essential in high intensity agriculture to maintain crop productivity. However, $\mathrm{Pi}$ is a non-renewable resource and, in conjunction with diminishing energy sources, this will in the future impact on fertiliser costs and food security [2]. It is therefore of high importance to fully understand the mechanisms employed by plants under $\mathrm{P}$ deficiency as a knowledge base for the development of smart plants with increased capacity to mine and efficiently use Pi. This will become an increasingly important factor in the necessary sustainable intensification of productivity to feed a growing world population.

\section{Biomed Central}

(c) 2014 Secco et al.; licensee BioMed Central Ltd. This is an Open Access article distributed under the terms of the Creative Commons Attribution License (http://creativecommons.org/licenses/by/2.0), which permits unrestricted use, distribution, and reproduction in any medium, provided the original work is properly credited. The Creative Commons Public Domain Dedication waiver (http://creativecommons.org/publicdomain/zero/1.0/) applies to the data made available in this article, unless otherwise stated. 
Plants have developed adaptive strategies to cope with limiting Pi availability. These physiological and developmental adaptations are collectively referred to as phosphate starvation response (PSR). This includes the transcriptional induction of genes coding for high-affinity phosphate transporters (PHTs) or purple acid phosphatases (PAPs) to increase uptake capacity and mobilisation of $\mathrm{Pi}$ [3]. In addition, members of the SPX domain containing protein family (e.g. PHO1, SPX-MFS, NLA) involved in the regulation of $\mathrm{Pi}$ homeostasis, and enzymes re-modelling membrane lipid composition to remobilise Pi from phospholipids such as monogalactosyl diacylglycerol synthases (MGDs) and UDP-sulfoquinovose:DAG sulfoquinovosyltransferase (SQD2), are also differentially expressed $[4,5]$. A central component of the PSR is the miRNA399/PHO2/PHR1 regulon. In Pi limited conditions the expression of miRNA399 is highly up-regulated by the transcription factor PHR1 leading to the degradation of its target PHO2. This E2 ubiquitin conjugase regulates protein turn-over of target proteins that include $\mathrm{PHO} 1$ and $\mathrm{Pi}$ transporters [6-9]. Morphological changes in root system architecture such as a decreased primary root growth and increased lateral root formation have been analysed on the molecular level in Arabidopsis [10]. Specialised root structures termed cluster roots formed on lateral roots by dense rootlets of limited growth can be found in a diverse range of plant families such as the Fabaceae and Proteaceae $[11,12]$.

White lupin (Lupinus albus) has become a model plant for the analysis of cluster root (CR) biology [13]. CR formation is a highly complex process in which developmental changes such as the initiation of lateral roots in addition to metabolic adjustments e.g. increased carboxylate production and secretion, have to be integrated to ensure their functioning. In white lupin foliar application of $\mathrm{Pi}$ inhibits cluster root development, providing evidence that systemic signalling is involved in cluster root formation [14]. By contrast, local sensing of Pi-rich soil patches induces cluster root formation to increase root surface area [15]. In addition, the secretion of large amounts of carboxylates such as citrate and malate from mature cluster roots ('exudative burst') generates a high and localised concentration able to mobilise Pi from insoluble forms [16].

The plant hormones auxin and cytokinin are important players in the regulation of cluster root development which is not surprising given their central function in the control of root development identified in non-cluster root forming model species such as Arabidopsis [17]. In this species auxin is involved in the root architectural changes under Pi deficiency leading to reduced primary root growth and increased lateral root formation [18-20]. Cytokinin has an antagonistic role to auxin by promoting cell differentiation, inhibition of lateral root formation and preventing their formation in close proximity to each other [21-23]. In white lupin there is also increasing evidence for an involvement of auxin in the control of cluster root formation. The exogenous application of auxin promotes cluster root formation while auxin transport inhibitors have an impeding effect. Also, several genes involved in auxin signalling have been identified as expressed in developing cluster roots [24-26]. Similarly to observations on lateral root initiation in Arabidopsis, cytokinin also inhibits the formation of cluster roots in white lupin under Pi deficiency [26,27].

Here we analyse cluster root formation in white lupin under phosphate limitation by RNA-seq. This is the first study that analyses different developmental stages of a forming cluster root on a transcriptomic scale. Our nextgeneration sequencing data contribute to the available information on the white lupin transcriptome as a further step in developing this species into a model plant for cluster root biology. We identify a complex network of hormone pathways and transcription factors involved in the regulation of early cluster root formation. In addition, functional differences between the various parts of the cluster root in the acclimation to phosphate deficiency are discovered.

\section{Results}

Assembly of RNA-seq data and integration into LAGI01

For the analysis of gene expression in the developing white lupin roots, tissue from root tips (TCR), immature (ICR) and mature cluster roots (MCR) that developed in plants grown under P-deficient as well as root tips (TR) and mature roots (MR) of plants grown under P-sufficient conditions were harvested at the 6- to 8-trifoliolate stage. The generated RNA-seq libraries of three independent biological replicates for each treatment were then paired-end sequenced. After filtering for reads with a Phred score of +30 and a length above 90 bp a total of $133,045,174$ high-quality reads were used for a de novo assembly of the white lupin root transcriptome. Using the Velvet/Oases pipeline [28] a total of 46,383 contigs with an average size of 896 bp were obtained. The longest contig (LAGI02_264) is a 29,640 bp fragment that originated from contaminating mitochondrial DNA while the longest protein coding contig (LAGI02_265) is $16,579 \mathrm{bp}$ in size with $79 \%$ identity to the Cicer arietinum MIDAS-like mRNA, highlighting the ability of our assembly parameters to generate an assembly with high contig quality and lengths. In order to further improve the quality of our assembly, we merged it with a recently published white lupin transcriptome assembly (LAGI01, [26]), thus generating LAGI02 (Additional files 1, 2 and 3). After removal of contigs with a length below 200 bp, LAGI02 contains 65,097 contigs with an average size of 1,625 bp and a total length of 105,789,289 bp (Table 1, Additional file 4: Figure A). For the functional annotation contigs 
were first assigned to the best BLASTX hit against the NCBI database with a cut-off of $\mathrm{E}<10^{-15}$. The majority of primary BLAST hits are against sequences from legume species (Additional file 4: Figure B). Targeted homology searches against the Glycine max (Gmax_189 release) and Arabidopsis (TAIR10 release) genomes using BLAT were able to assign putative white lupin homologs for $96 \%$ and $44 \%$, respectively (Additional file 1 ). This extensive homology of soybean and white lupin sequences was then used to assign gene ontology terms to the LAGI02 contigs. Comparison of GOslim terms in the three main GO classes biological process (48\% of all assigned GO terms), cellular component (28\%) and molecular function (24\%) showed no major difference in the GOslim term distributions for the two species in accordance with their close phylogenetic relationship (Additional file 5). Functional characteristics annotation was also performed according to the Mapman functional bin classification [29], allowing the usage of this versatile tool in the visualisation of gene expression data in white lupin. Again, there were no major differences in the distribution of genes across the functional bins for LAGI02 when compared to the Gmax_189 and TAIR10 genome releases (Additional file 6). Taken together, LAGI02 presents a highly valuable resource for functional genomics studies in this emerging model species, e.g. for the analysis of cluster root development.

\section{P-deficiency induces genes of the classical phosphate starvation response in cluster root tissues}

Phosphorus-deficiency is the main cue to induce cluster root formation in white lupin and hence was used to determine differences in gene expression in the different stages of developing cluster roots (Additional file 7). The RNA-seq data were first used to assess differences in gene expression in the five collected tissues under $\mathrm{Pi}$ sufficient $(+\mathrm{P})$ and Pi-deficient $(-\mathrm{P})$ conditions (Additional file 8). Only transcripts with a FPKM value of above 5 in at least one tissue sample were called as expressed, leaving 32,204 transcripts for further analyses (Figure 1). Of these, 28,915 (90\%) transcripts were

Table 1 Characteristics of white lupin de novo assemblies

\begin{tabular}{llll}
\hline Parameter & LAGI01* $^{*}$ & This work & LAGI02 $^{\#}$ \\
\hline Kmer length & 29 & 67 & - \\
No. of reads & $277,224,180$ & $133,045,174$ & - \\
No. of contigs & 125,821 & 46,383 & 65,097 \\
Average contig length & 1,155 & 896 & 1,625 \\
\% GC & 39.6 & 40.03 & 39.4 \\
Longest contig & 15,514 & 28,229 & 26,640 \\
Total bases & $145,286,000$ & $41,550,474$ & $105,789,289$ \\
\hline
\end{tabular}

*reference: [26].

de novo assembly of the five analysed root tissues.

\#merged assemblies after removal of reads $<200$ bp and with no BLAST hit. expressed in all five samples, while the number of genes preferentially expressed in only one sample ranged from 228 transcripts in the MR sample to only 9 transcripts in the ICR sample (Figure 1).

In total $835(2.5 \%)$ transcripts were differentially expressed by more than 8 -fold in at least one pairwise comparison of samples form Pi-deficient and Pi-sufficient treatments. Hierarchical clustering of these transcripts identified five main clusters (Figure 2A). Interestingly, while the MCR and ICR group together, the TCR response was more closely related to those of the MR and TR. This indicates that there was a more limited response to P deficiency in the TCR than in the MCR or ICR. Clusters 1,2 and 5 are composed of transcripts with increased expression under $-\mathrm{P}$ condition. These three clusters included many transcripts homologous to the well-established phosphate-starvation induced (PSI) genes coding for e.g. purple acid phosphatases (PAPs), phosphate transporters (PHTs) or SPX proteins, with expression of these genes under $-\mathrm{P}$ highest in the MCR (Figure $2 \mathrm{~B}$ and Additional file 9). The relative response of genes in Clusters 1 and 5 to $-\mathrm{P}$ conditions was identical but with genes in Cluster 5 generally having an approximately 3 -fold higher expression level. In both these clusters expression of genes was

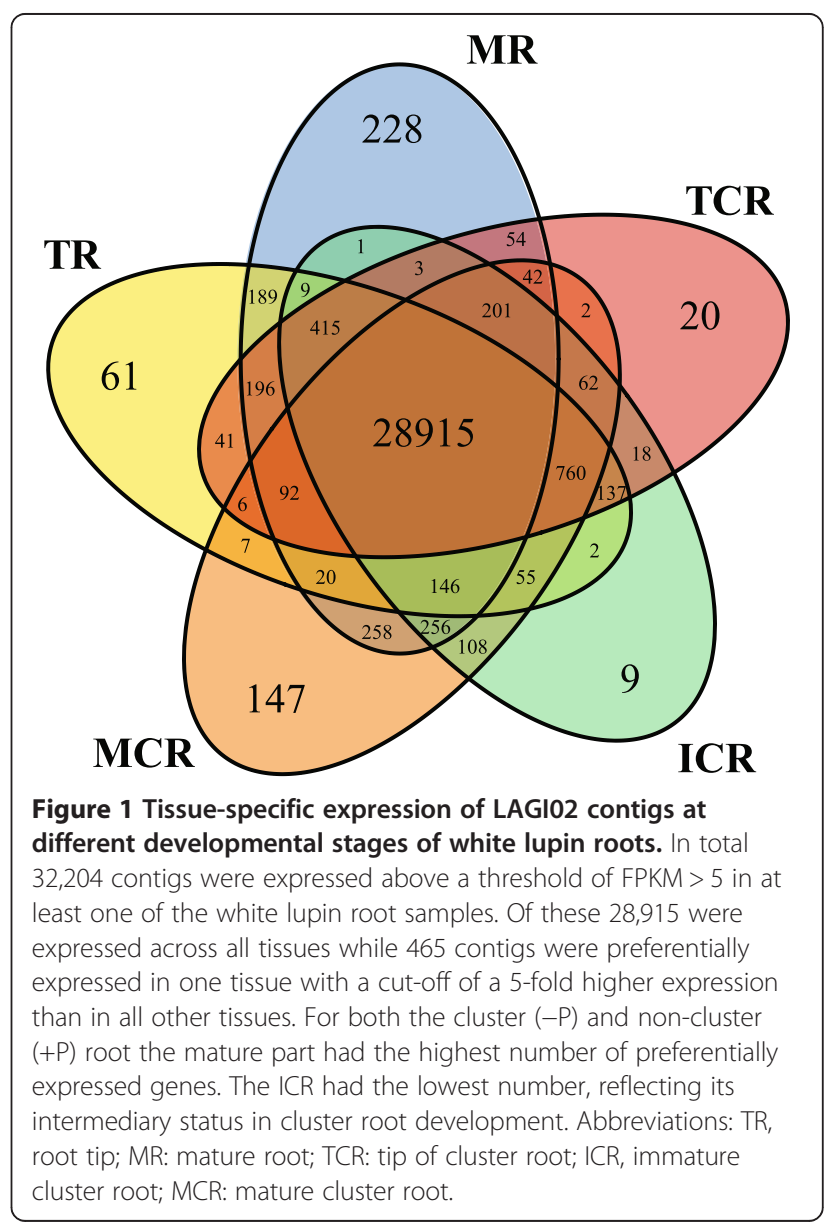


A
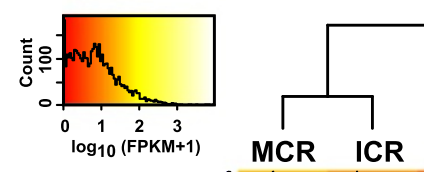
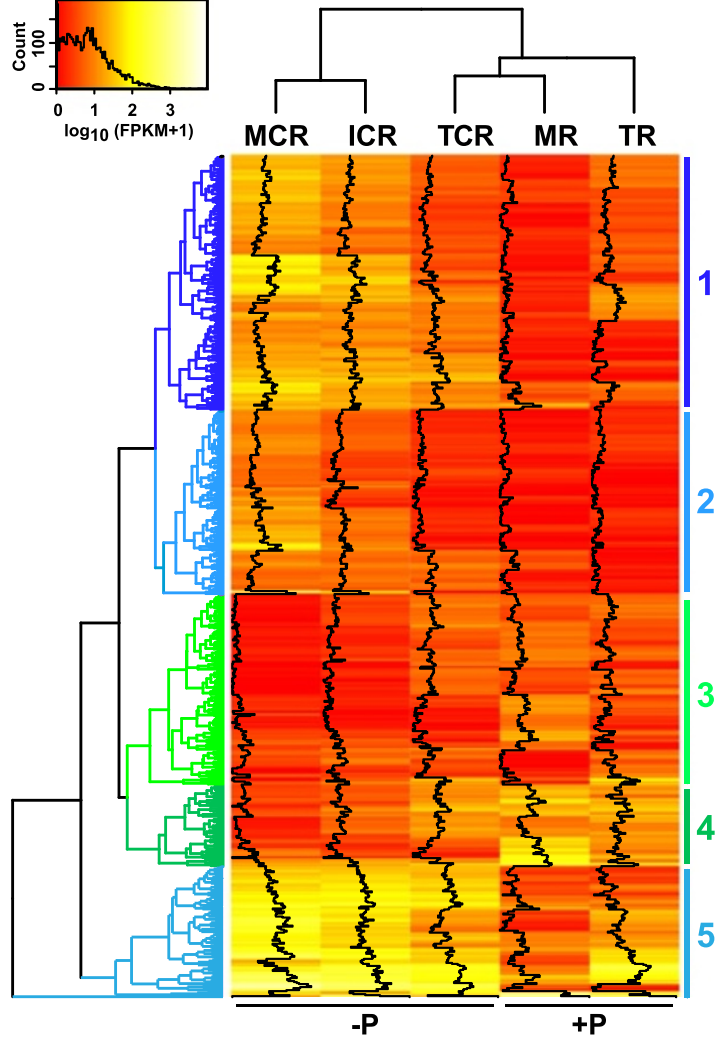

B
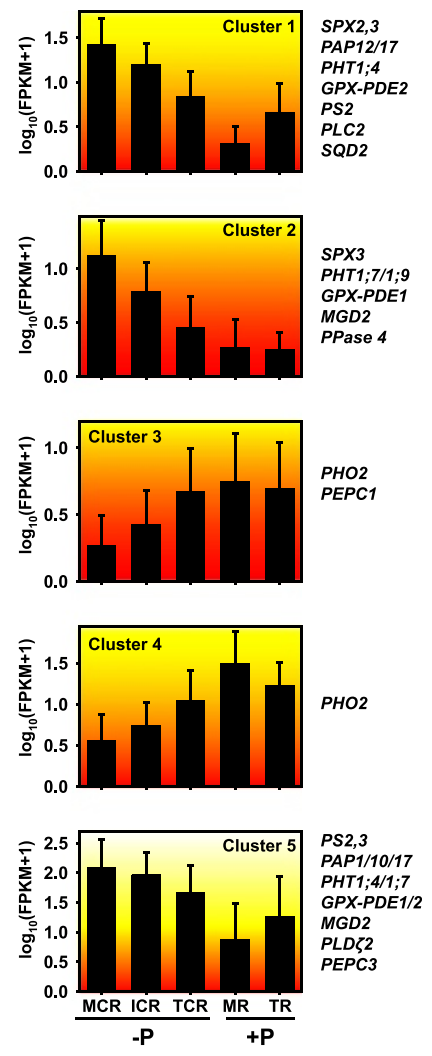

Figure 2 Hierarchical clustering of LAGI02 contigs differentially expressed under phosphate deficiency. A) Heatmap of $\log _{10}($ FPKM +1$)$ values for the expression of LAGI02 contigs in the different analysed white lupin root tissues. Shown are only the 835 contigs with an higher than 8-fold up- or down-regulation in at least one pair-wise comparison of tissues. Hierarchical clustering using the Manhattan distance identified five main clusters. Clusters 1, 2 and 5 contained genes up-regulated by P-deficiency and more highly expressed in the mature cluster root than in the immature cluster root and the tip. B) Average expression pattern of genes in the main five clusters (means \pm SD). In addition, known P-deficiency responsive genes within each cluster are given. For contigs the name of the identified homologous Arabidopsis genes are given. Abbreviation: SPX, SPX DOMAIN; PAP, PURPLE ACID PHOSPHATASE, PHT1, PHOSPHATE TRANSPORTER1; GPX-PDE, GLYCEROPHOSPHODIESTER PHOSPHODIESTERASE; PS, PHOSPHATE STARVATION, PLC, PHOSPHOLIPASE C; SQD, SULFOQUINOVOSYLDIACYLGLYCEROL; MGD, MONOGALACTOSYL DIACYLGLYCEROL SYNTHASE; PPASe, PHOSPHORYLASE, PHO2, PHOSPHATE2; PEPC, PHOPSPHOENOLPYRUVATE CARBOXYLASE; PLDZ2, PHOSPHOLIPASEZ2.

lower in the MR than in the TR tissue while in Cluster 2 these were overall very similar. Clusters 3 and 4 contained transcripts down-regulated by $\mathrm{P}$ deficiency including PHOSPHATE 2 (PHO2) and a phosphoenolpyruvate carboxylase (PEPC) isoform as known phosphate starvationresponsive genes (Figure $2 \mathrm{~B}$ ). Our results therefore confirm the transcriptional regulation of gene expression induced by phosphate starvation and the value of LAGI02 as a resource for transcriptomic studies.

\section{Transcriptional control of metabolic acclimation to P deficiency}

Thus far, no genome-wide transcriptomic study investigating the response of different developmental stages of a cluster root has been published. We therefore analysed our dataset for differences in the response of the three tissues under phosphate starvation. When analysing expression of classical PSI genes in the same tissues of plants grown under $-\mathrm{P}$ and $+\mathrm{P}$ conditions, i.e. $\mathrm{MCR}$ vs. MR and TCR vs. TR, genes belonging e.g. to the PHT1, $S P X$ and PAP family showed a very similar response in the two tissue comparisons (Additional file 9). This indicates that the primary transcriptional response of genes directly involved in phosphate acquisition and homeostasis are regulated to a similar degree across the different stages of cluster root development.

However, there was a pronounced difference in the expression of genes implicated in the metabolic acclimation to low P supply. In the mature part of the root, phosphate deficiency induced a high number of genes by more than 4-fold coding for enzymes involved in primary carbon metabolism, i.e. the TCA cycle, glycolysis, Calvin cycle, and mitochondrial ATP synthesis (Figure 3A). For the TCA cycle, up-regulated genes code for dihydrolipoamide $S$ - 

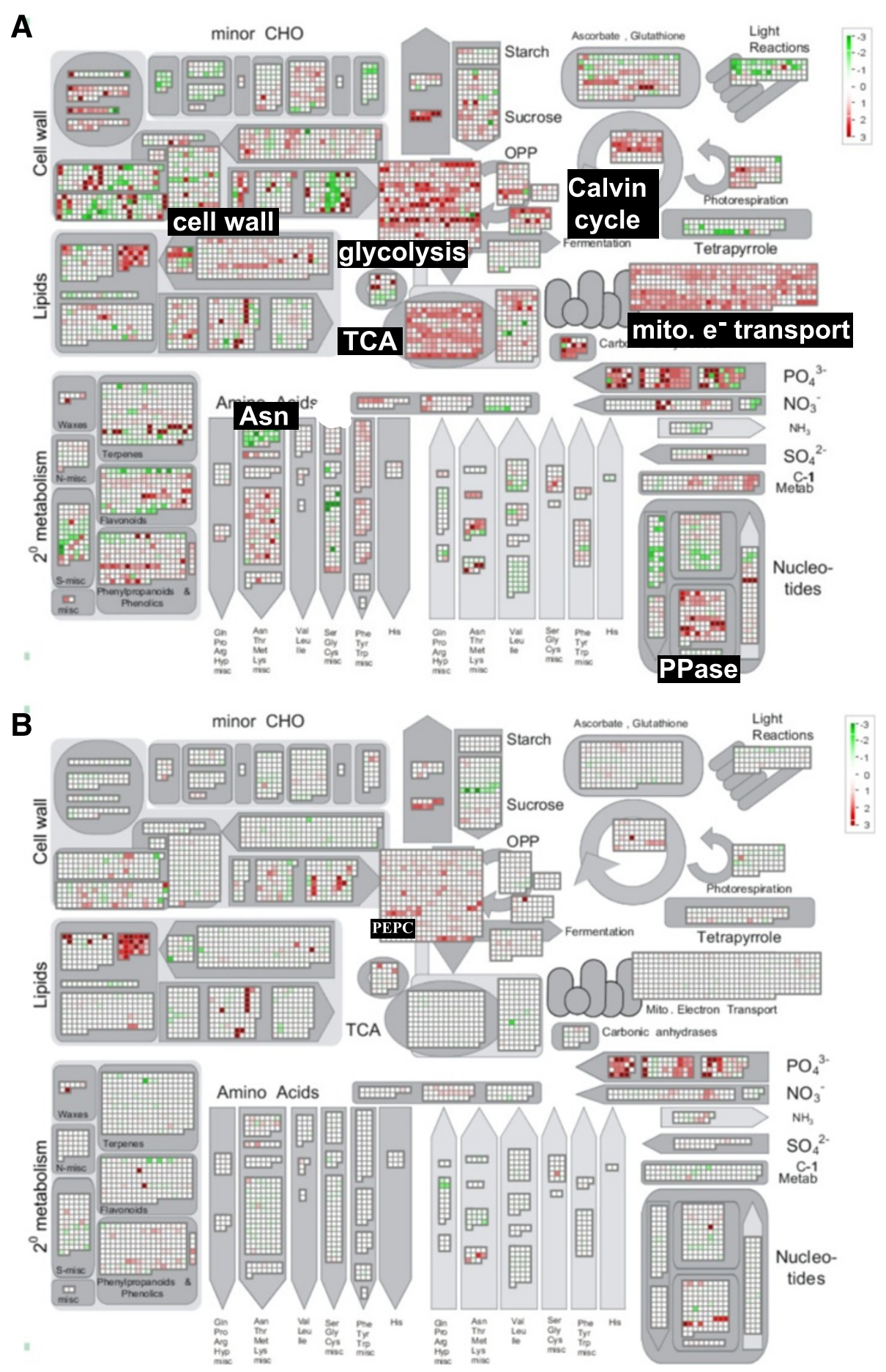

Figure 3 Mapman representation of differential gene expression for the mature root and root tips under altered $P$ supply. Comparison of gene expression in the mature root cluster root and non-cluster root (A, MCR vs. MR) and root tips (B, TCR vs TR), i.e. P-deficient versus P-sufficient tissues for genes involved in primary metabolism. In the comparison of P/+P mature root many genes related to the TCA cycle, glycolysis or Calvin cycle showed higher expression in the MCR than in the MR while such a response was not observed for the root tips. Here, with the exception of PEPC, only genes directly involved in P homeostasis or lipid remodelling showed higher expression in the TCR. Given are $\log _{2}$ values for corresponding FPKM ratios. Red colour highlights up-regulated, green colour down-regulated genes. 
acetyltransferase, malate dehydrogenase and pyruvate dehydrogenase. Among the highest up-regulated glycolysisrelated genes are phosphoenolpyruvate carboxylase, glyceraldehyde-3-phosphate dehydrogenase and enolase. Induced Calvin cycle genes are encoding transketolase and aldolase. Most highly regulated among all was malate synthase with a more than 100-fold higher expression in the MCR than in the MR. This was accompanied by an induction of plasma membrane $\mathrm{H}^{+}$-ATPases and membrane transporters of the MATE family by about 10-fold (Additional file 10). A similar response was not induced in the root tip of P-deficient plants when compared to the TR in non-cluster roots. The only gene upregulated to similar degree as in the MCR/MR comparison was PEP carboxylase (Figure 3B).

In addition, several genes coding for membrane transporters were differentially expressed between MCR and TCR (Additional file 10). Interestingly, there was also a differential response of nitrate, ammonium and sulfate transporters. While a nitrate transporter homologous to NRT1.5 involved in root to shoot transport of $\mathrm{NO}_{3}^{-}$in Arabidopsis was more highly expressed in the MCR, several others (e.g. NRT1.7, NRT2.4) showed higher expression in the TCR. Similarly, lupin homologs of sulfate transporters belonging to the SULTR3 family (SULTR3;1, SULTR3;5) were more abundant in the MCR and highaffinity transporters such as SULTR1;1 and SULTR1;3 showing higher expression in the TCR (Additional file 10).

Taken together, these results show that with the exception of genes directly involved in uptake and homeostasis of phosphate the cluster root tip was not involved in the metabolic acclimation of the cluster root to phosphate deficiency. Only genes directly involved in the uptake or recycling of phosphate were transcriptionally responding in this tissue. By contrast, the mature part of the cluster root was solely responsible to sustain the exudative burst and necessary anaplerotic reactions, thus also supporting Pi uptake of the root tip by making insoluble Pi available through exudation of carboxylates.

\section{Regulation of cluster root formation by hormones and transcription factors}

To gain a better understanding of the regulatory processes involved in cluster root formation we next analysed our data for difference in gene expression across the different stages of the cluster root (Figure 4). Our analyses identified 747 genes differentially expressed by more than 8 -fold in at least one pair-wise comparison of the three analysed developmental stages. Hierarchical cluster analysis showed five main clusters with Clusters 1 and 2 containing the majority of genes (Figure 4A). Cluster 1 is composed of genes with a low expression in the MCR and increasing expression in the two younger cluster root stages ICR and TCR, respectively (Figure 4B). By contrast, genes in
Cluster 2 have a high expression in the MCR, decreasing towards the TCR. Genes in Cluster 3 have an identical pattern across the tissues as Cluster 2 but at a higher expression level. Cluster 4 and 5 contain only a small number of genes compared with the other clusters, with Cluster 4 including genes preferentially expressed in the ICR and TCR, and Cluster 5 showing genes with high expression especially in the MCR (Figure 4B).

We next performed analyses for GO term enrichment of genes in Cluster 1 and genes in Clusters 2 and 3 combined. This showed an enrichment of GO terms related to root growth and development, cell cycle/growth and auxin for Cluster 1 (Figure 5A and Additional file 11). Genes associated to these are homologs of cyclins (CYCA1/2, CYCB2), cyclin-dependent kinases (CDKB2), auxin transporters (PIN1, LAX2/3), auxin signalling-components $(A u x / I A A$, $A B P 19)$, auxin-dependent cell growth regulators (NPH3, WAT1) and auxin-synthesis enzymes (YUC2, IAMT1) (Figure 4B). Most of these genes show higher expression in the younger stages of the cluster root than in the mature part and little difference in a TCR vs. ICR comparison (Figure 6A). Only the WAT1 gene, coding for a tonoplast-localised protein involved in secondary wall formation, showed a higher expression in the TCR than in the ICR and the MCR. In the P-sufficient white lupin root a similar expression pattern of these genes was absent, likely because an initiation and formation of laterals to form a cluster root was not induced.

For Clusters 2 and 3 we identified only a limited number of GO terms enriched (Figure 5B and Additional file 11) with associated genes relating to oxidative stress ( $P R X$, $F B A, G A P-D H, A N N E X I N)$ and iron homeostasis (FER, $V I T)$ (Figure 6A). These genes have lower expression in the younger stages of the cluster roots, e.g. homologs of the iron uptake regulator FER and peroxidase show a 30fold and 15-fold lower expression in the TCR than the MCR (Figure 6A). This is in agreement with results identifying oxidative stress through reactive oxygen (ROS) production as a confounding effect of phosphate starvation $[30,31]$. Our results provide evidence that this is more so in the mature part of the cluster root, likely as a consequence of the higher metabolic activity. However, the peroxidase homologs were more highly expressed in the root tip than in the mature part of P-sufficient plants.

Given the extensive differences observed in the transcriptomes of the three cluster root stages and the complex developmental changes involved it is not surprising we also observed differences in gene expression levels for several transcription factors (TFs) across the three cluster root samples other than the already described AUX/IAA and FER. For several contigs with homology to the AP2/ ERF class TFs of the PLETHORA family (PLT2/3/7) expression was about 30- and 10-fold higher in the cluster root tip than in the immature and mature cluster root 


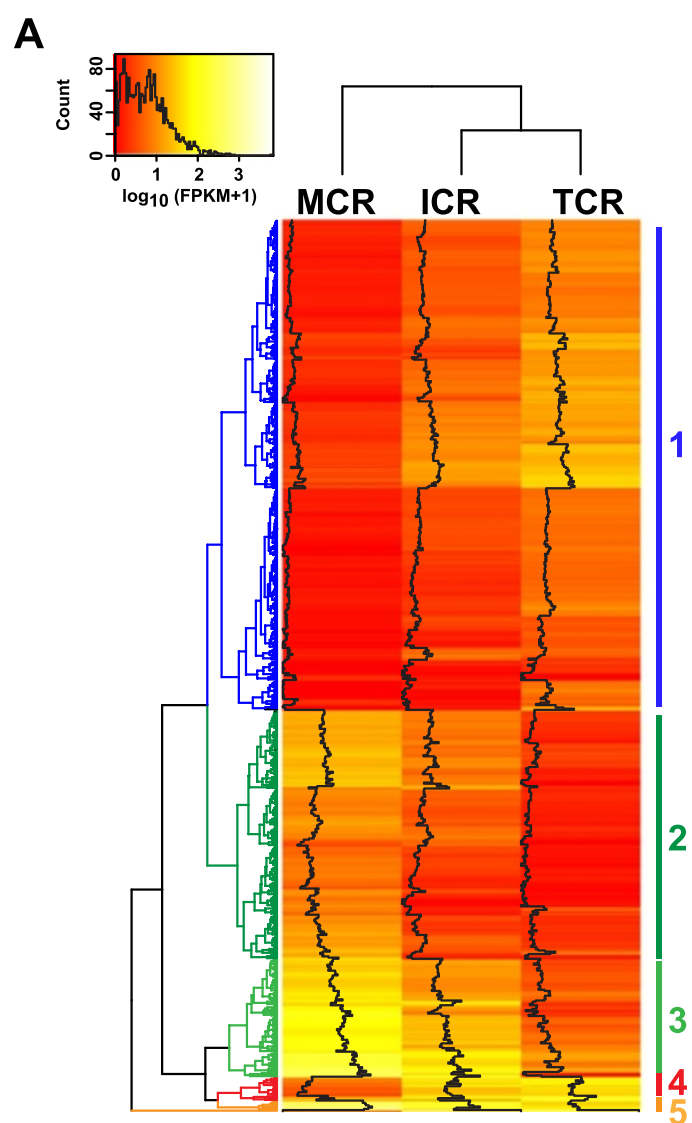

B

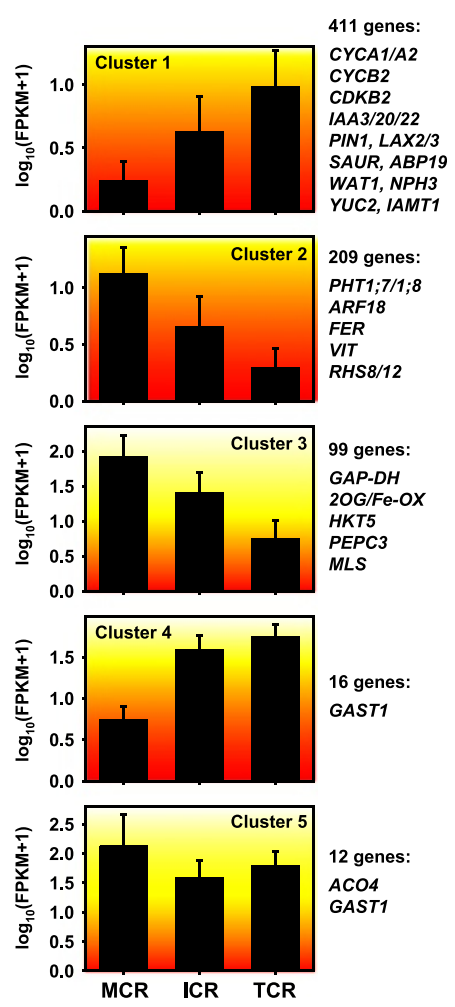

Figure 4 Hierarchical clustering of genes differentially expressed across developmental stages of cluster root. A) Hierarchical cluster analysis gave five main clusters for the 747 contigs showing differential expression in at least one pair-wise comparison of the three analysed cluster root tissues. B) Average expression pattern of contigs in the main five clusters (Given are means \pm SD). Known P-deficiency responsive genes within each cluster are also indicated. Cluster 1 contained genes with highest expression in the root tip of the cluster root and decreasing towards the mature part. GO term analysis identified that this cluster was enriched for genes with functions in cell cycle regulation and auxin-mediated growth control. By contrast, genes in Cluster 2 and 3 showed the opposite expression pattern and are involved in iron homeostasis and oxidative stress response. In comparison, Clusters 4 and 5 only had few genes without any GO term enrichment. For contigs the name of the identified homologous Arabidopsis genes are given. Gene abbreviations are: 2OG/Fe-OX, 2-OXOGLUTARATE AND FE(II)-DEPENDENT OXYGENASE; ABP, AUXIN BINDING PROTEIN; ACO, 1-AMINOCYCLOPROPANE-1-CARBOXYLATE OXIDASE; ARF, AUXIN RESPONSE FACTOR; CYC, CYCLIN; CDK, CYCLIN-DEPENDENT KINASE; FER, GAP-DH, GLYCEROALDEHYDE DEHYDROGENASE; GAST, GIBERELLIC ACID STIMULATED TRANSCRIPT; HKT, HIGH AFFINITY K' TRANSPORTER; IAA, INDOLE ACETIC ACID-INDUCIBLE; IAMT, IAA CARBOXYLMETHYLTRANSFERASE; LAX, LIKE AUXI; MLS, MALATE SYNTHASE; NPH, NON PHOTOTROPIC HYPOCOTYL; PEPC, PHOSPHOENOL PYRUVATE CARBOXYLASE; PHT, PHOSPHATE TRANSPORTER; PIN, PIN-FORMED; RHS, ROOT HAIR SPECIFIC; SAUR, SMALL AUXIN UP-REGULATED RNA; VIT, VACUOLAR IRON TRANSPORTER; WAT, WALLS ARE THIN; YUC, YUCCA.

tissues, respectively, while it was not changed in the Psufficient MR and TR (Figure 6B). Similarly, homologs of the homeodomain-leucin zipper transcription factor ATHB2 were most highly expressed in the TCR. Several other TFs (SCR, MGP, WOX5, PHB, PHV) of the regulatory network controlling the activity and cell fate within the root meristem also show higher expression in the TCR (Figure 6B). For these there is an at least 8-fold higher expression in the TCR than in the MCR and little difference between TR and MR. Interestingly, the expression of a homolog of the bHLH transcription factor UPB1 (UPBEAT1), a repressor of peroxidase expression and central regulator of ROS balance controlling the transition from proliferation to differentiation in the root [32], was contrasting with peroxidase expression in the cluster roots but not the non-cluster root (Figure 6A and B).

Cytokinin $(\mathrm{CK})$ is also an important regulator of cell differentiation within the root and also repressed the expression of $P H B$ and miRNA165. Therefore CK is also a component of the regulatory network governing root development [23]. Correspondingly, several LAGI02 contigs with sequence homology to the Arabidopsis cytokinin oxidases (CKX) involved in CK degradation, are down-regulated by about 5-fold in the TCR when compared to the MCR (Figure 6A). At the same time a lupin homolog of the Arabidopsis cytokinin receptor CRE1 was about 5-fold more highly expressed in the TCR than in the MCR. These gene expression patterns 


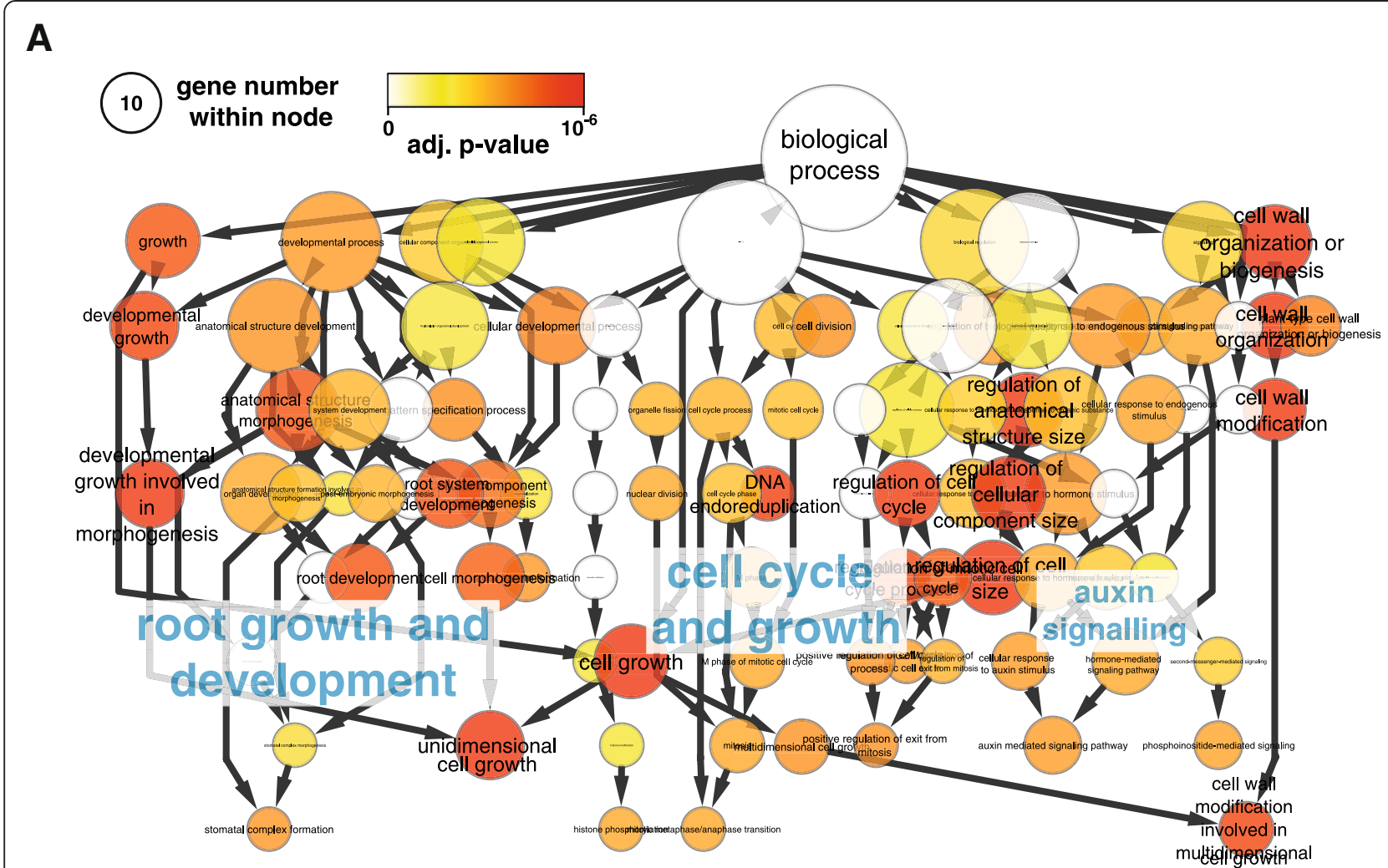

B

gene number
within node

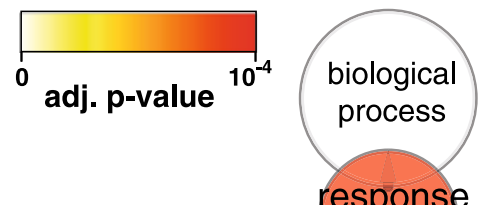

to stimulus

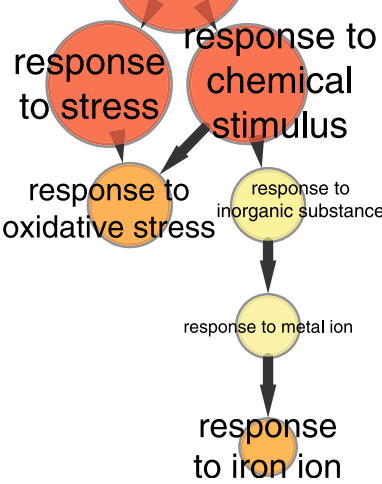

Figure 5 Analysis of GO term enrichment for differentially expressed genes in the three analysed stages of cluster root development. Over-represented GO terms for genes with higher expression in A) the TCR (see Figure 4, Cluster 1) and B) the MCR (see Figure 4, Clusters 2 and 3). Analysis was performed using the BiNGO plugin for Cytoscape with Benjamini-Hochberg FDR correction $(p<0.01)$ and results plotted in a $y$-hierarchical representation. The circle areas represent the number of genes associated to a given $\mathrm{GO}$ term and color reflects the adjusted $\mathrm{p}$-value. 

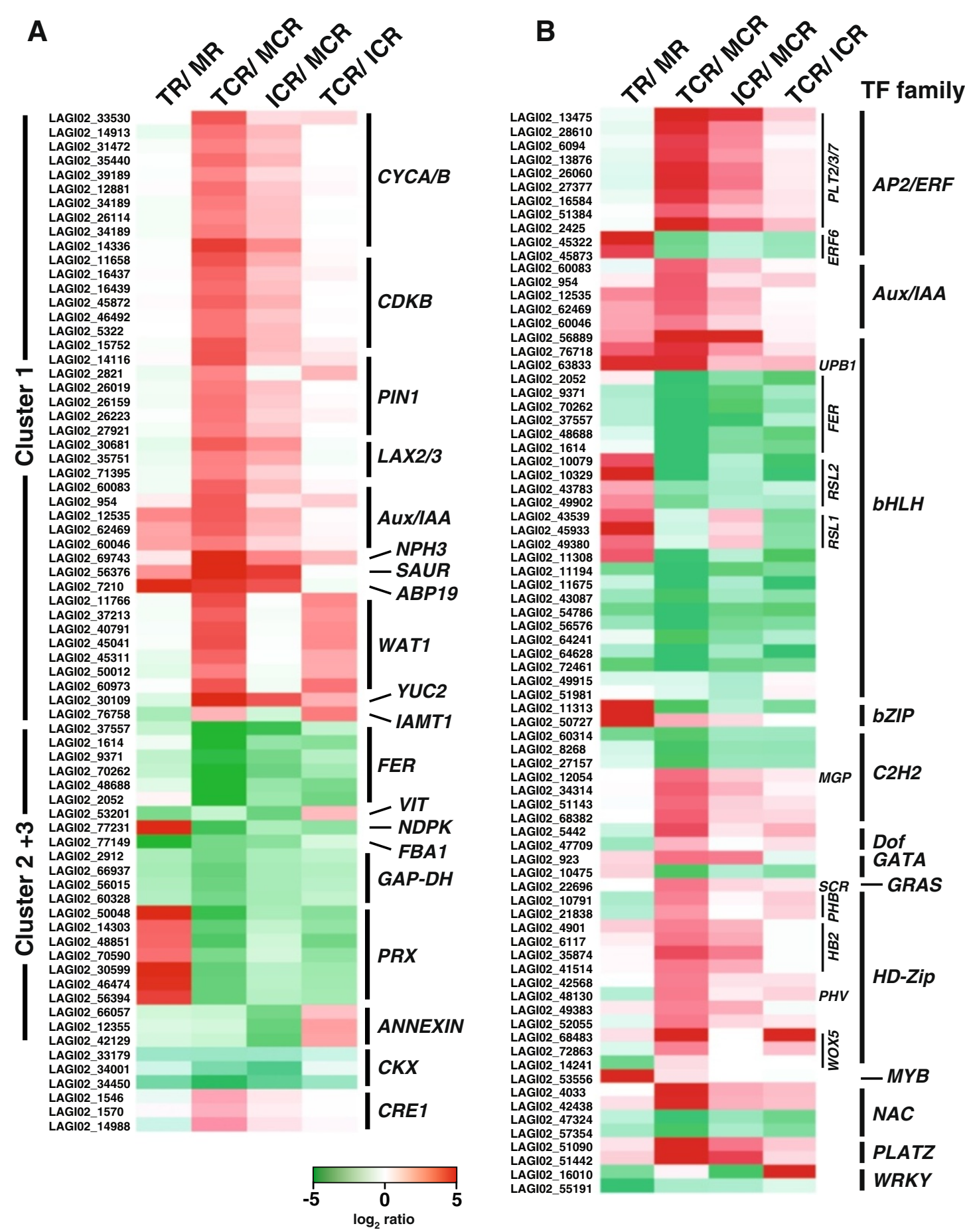

Figure 6 Differential expression of gene identified by GO term enrichment analysis and of transcription factors. A) Shown is differential expression of genes associated to enriched GO terms in Cluster 1 (cell cycle, auxin, root development) and Clusters $2+3$ (oxidative stress, response to iron) of the hierarchical cluster analysis (Figure 4). Additionally, white lupin homologs for two genes involved in cytokinin signalling, cytokinin oxidase (CKX) and the cytokinin receptor CRE1 are presented. For contigs the name of the identified homologous Arabidopsis genes are given. Gene abbreviations are: FBA, FRUCTOSE 1,6 BIPHOSPHATE ALDOLASE; NDPK,NUCLEOSIDE DIPHOSPHATE KINASE; PRX, PEROXIDASE. For other gene abbreviations see Figure 4.

B) Differentially expressed transcription factors shown as pair-wise comparisons for non-cluster root and cluster root tissues, respectively. Individual genes were grouped into the corresponding TF families. Gene abbreviations: ERF, ETHYLENE RESPONSE FACTOR; HB2, HOMEOBOX PROTEIN2; MGP, MAGPIE; PHB, PHABULOSA; PHV, PHAVOLUTA; PLT, PLETHORA; RSL, ROOT HAIR DEFECTIVE SIX-LIKE; SCR, SCARECROW; UPBI, UPBEAT1; WOX, WUSCHEL-RELATED HOMEOBOX. Differential expression of genes in the tissues of the P-sufficient root and P-deficient cluster root tissues in $\mathbf{A}$ ) and $\mathbf{B}$ ) are given as $\log _{2}$ of the FPKM ratios. 
suggest an increase in local cytokinin concentration and CK sensitivity towards the root tip to remove inhibition of lateral root development and observed responsiveness of PSR genes [33,34].

Thus, our data identified a complex regulatory circuit of transcription factors and of the plant hormones auxin and cytokinin involved in the initiation of cluster roots in white lupin. These prime lateral root formation, promote their initiation and elongation under P-limited conditions.

\section{Identification of pri-miRNAs expressed in the cluster root}

LAGI02 contains sequences with homology to known primary transcripts of miRNAs (pri-miRNAs) and allowed us the identification of corresponding pre-miRNA hairpin structures and their mature miRNA sequence. These were very similar between lupin and soybean with minor difference in the hairpin structure outside of the highly conserved miRNA/miRNA* region (Additional file 12). Recent studies have profiled the abundance of miRNAs and identified putative targets of lupin miRNAs [26,35]. Our data add to the complement of miRNA in the developing cluster roots. Interestingly, we did not identify a precursor of miRNA399, a key regulator of the phosphate starvation response [6,7], in our dataset although lupin homologs of its target $\mathrm{PHO} 2$ contain a sequence complementary to miRNA399 [26]. Most of the identified primiRNAs show a similar abundance across the different analysed tissues and irrespective of $\mathrm{P}$ supply (Figure 7). However, the abundance of miRNA156 is about 2-3-fold higher in the P-deficient cluster root tissues which is in agreement with reports identifying this miRNA as Pdeficiency induced in white lupin and Arabidopsis [36]. Targets of miRNA156 include the SQUAMOSA PROMOTER BINDING PROTEIN-like family members SPL3/ 4/5. The pri-miRNA166 and 393 showed highest abundance in the MR and TR/ICR, respectively. This could either be a sign of higher expression in this tissue or of a higher turn-over followed by increased degradation of target mRNAs in the MCR and TCR.

\section{Discussion}

\section{Metabolic acclimation to P-limitation}

Cluster root formation is an important adaptive trait to cope with limiting P-availability in several plant species. Analysis of the molecular mechanisms underpinning this complex developmental process will give a better understanding of the ways plants cope with limited P supply. Advances in next-generation sequencing technology permit probing for transcriptome-wide changes in gene expression in non-model species such as white lupin. Incorporation of our RNA-seq data into the existing data set [26], thus generating an improved sequence resource, in conjunction with functional gene annotation, will allow white lupin to become a molecular model species for the analysis of cluster root development. We have started to exploit this resource by analysis of transcriptomic differences in several stages of cluster root formation. Phosphate starvation-induced changes in gene expression were very similar when comparing root tip and mature parts of P-sufficient with P-deficient plants,

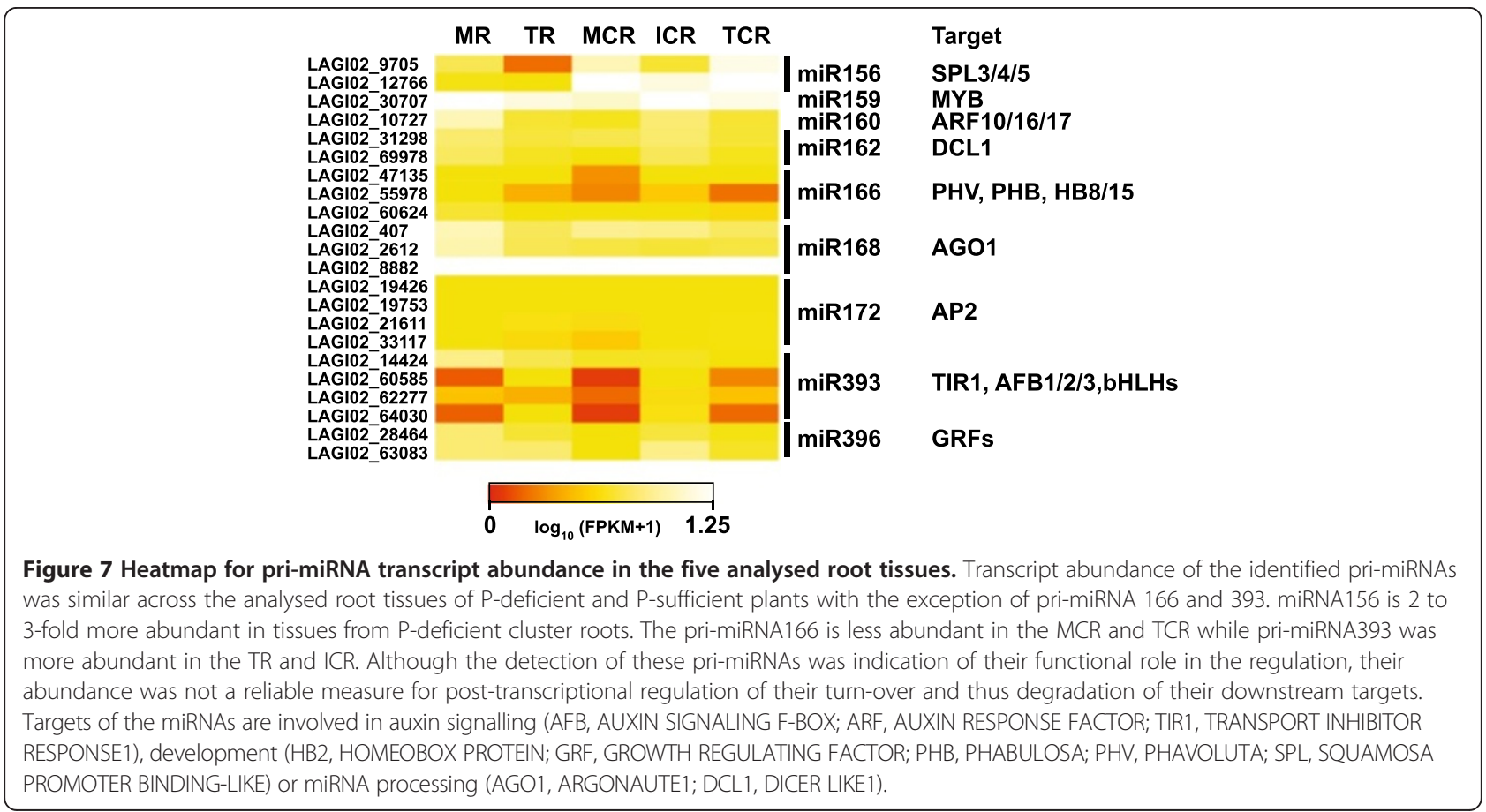


respectively. This included mainly well characterised genes involved in the uptake, re-distribution and homeostasis of phosphate, i.e. phosphate transporters, SPX-domain genes or genes involved in lipid remodelling. Very similar sets of genes have been identified in studies of the root transcriptome in species such as white lupin [26], Arabidopsis [37-39] and rice [40-42]. By contrast, tissue-specific differences identify functional specialisation of the different cluster root stages of P-starved plants. In the MCR changes in gene expression are geared to support the metabolic reactions involved in the synthesis and secretion of large amounts of organic acids, i.e. up-regulation of genes belonging to the TCA cycle or glycolysis. This confirms earlier results in a spatially higher resolution and on a transcriptome-wide scale $[26,43]$. Our results indicate that the root tip is not producing or exporting organic acids and depend for this on the mature part of the cluster root. However, the root tip increases Pi uptake and acquisition capacity to profit from the exudative burst and subsequently liberated phosphate from insoluble complexes.

Previously, a close link between the regulation of sulfate and nitrate homeostasis under phosphate deficiency has been shown [44-46]. We identify an extra level of complexity by which the uptake and translocation of these anions between the various tissues of the developing cluster root is regulated. In addition, sustained uptake of iron under phosphate starvation can lead to iron toxicity and therefore reduced iron uptake is a mechanism to protect meristem activity [47]. The down-regulation of a homolog of the transcriptional regulator of iron responses FER/FIT and a vacuolar iron transporter VIT in the TCR confirms this interconnection of iron and phosphate homeostasis and its importance for the root tip $[40,48,49]$.

\section{Hormonal control of cluster root development}

Cluster root formation provides insight into how plants use general regulatory components to form specialised structures to adapt to their environment. We show that white lupin uses the same set of plant hormones (i.e. auxin and cytokinin) and transcription factors identified in model plant species with a less complex root architecture, such as Arabidopsis and rice [50,51], to initiate and regulate cluster root formation. The increased expression of $C Y C$ and $C D K$ genes towards the cluster root tip reflects the cell proliferation and divisions occurring in the meristematic zone of the tip and the initiation of laterals from pericycle cells in the differentiation zone [51]. Several genes of the auxin-mediated signalling cascade are differentially expressed in the analysed cluster root stages with higher transcript abundance in the root tip. The auxin efflux carriers of the PIN family are essential to generate the auxin gradient within the root by polar transport towards the tip following the 'fountain model', leading to the primed state of lateral root founder cells and thus controlling lateral root initiation [52,53]. Members of the LAX auxin-influx carrier family are involved in the auxin accumulation close to the lateral root primordium promoting lateral root emergence [54], while the Aux/IAA protein family in conjunction with auxin response factor (ARFs) regulate the expression of downstream genes [55]. The high expression of YUC2 and IAMT1 towards the cluster root tip points to the importance of local auxin synthesis in cluster root formation. YUC2 is directly involved in the synthesis of auxin and has been shown to be expressed in the root meristem in Arabidopsis [56,57]. This flavin-monooxygenase is part of the main auxin biosynthetic pathway and catalyses the conversion of the precursor indole-3-pyruvic acid into the active auxin IAA [57]. Recently, a role for root-derived auxin in cluster root formation has also been shown in white lupin [25] and here we identify YUC2 as a likely biosynthetic enzyme involved. IAMT1 encodes an IAA carboxyl methyltransferases converting IAA to methylIAA ester and involved in the regulation of auxin homeostasis [58]. The two genes NPH3 and WAT1 regulate growth by modification of the subcellular targeting of the auxin efflux carrier PIN2 and secondary cell wall formation by altering root auxin concentration, respectively $[59,60]$. Recently, CK has also been identified as an important signalling component in the Pi-deficiency induced changes in lupin root architecture [26]. In addition, studies in Arabidopsis have shown that CK prevents the initiation of lateral roots in close proximity. The observed lower expression of the CK degrading enzyme CKX and the up-regulation of the CK receptor CRE1 towards the cluster root tip provides evidence that the formation of cluster roots depends on a localised accumulation and increased ability to perceive CK in this part of the root to allow for the dense formation of lateral roots [22].

\section{Differentially expressed transcription factors}

Several transcription factors (TFs) known to regulate root meristem function and lateral root initiation in Arabidopsis are also differentially regulated in the three cluster root stages of white lupin. Members of the PLETHORA (PLT) family of TFs regulate cell proliferation, elongation and differentiation via an auxin-induced expression gradient along the root [61]. In Arabidopsis the GRAS TF family member SCARECROW (SCR), the zinc finger TF MAGPIE (MGP) and the HD-Zip TF WOX5 are major regulators in maintaining the stem cell niche in the quiescent centre of the root meristem. SCR is also involved in the differentiation process leading to the specific root tissue types [51]. Additionally, SCR forms a regulatory network together with the transcription factors PHABULOSA and PHAVOLUTA (PHB/PHV), two TFs also 
differentially expressed in the TCR and MCR, and microRNA165/6 to consolidate cell identities in the developing root [62]. Interestingly, PHB has recently been shown to regulate cytokinin (CK) signalling by activating the CK biosynthesis gene IPT7 [23]. Root hairs are an important site of nutrient uptake as they increase root surface area and in white lupin their formation is induced already two days after lateral root emergence [16]. In agreement with this is the expression of homologs of the central regulator of root hair formation RSL1 in the ICR and RSL2 towards the mature part of the cluster root. These bHLH-type transcription factors are essential for root hair development and consequently mutants of the corresponding genes in Arabidopsis, Lotus and Physcomitrella are deficient of root hairs [63-65].

The detected down-regulation of the lupin TF homolog of ERF6, a regulator of the response to oxidative stress [66], is in agreement with the ROS-related stress induction under phosphate limitation. The accumulation of $\mathrm{H}_{2} \mathrm{O}_{2}$ in the root cortex has been observed for P-deprived Arabidopsis plants [67]. Interestingly, we also found a contrasting expression of the TF UBP1 and peroxidases in the cluster root. In Arabidopsis UBP1 regulates the expression of peroxidases within the root tip, thereby modulating the distribution of ROS species and controlling the transition from proliferation to differentiation [32]. Together, these results may indicate that reactive oxygen species are signalling molecules, but also products of oxidative stress, that require a complex regulation of local concentrations in the developing white lupin cluster root.

\section{White lupin pri-miRNAs}

In addition to plant hormones and transcription factors, miRNAs are also important components in the regulation of root development [68]. We have been able to identify several primary transcripts of miRNAs (pri-miRNAs) expressed in the white lupin cluster root. We could not identify a homolog of pri-miRNA399, a highly induced miRNA under P-deficiency, in our cluster root assembly. This is not surprising as the mature miRNA in white lupin has been found exclusively in leaves, showing an upregulation under P-limited growth conditions [35], likely to serve as a phloem-mobile signal [69,70]. miRNA156 was more abundant in cluster roots than in the P-supplied roots. Although the function of this miRNA in the regulation of $\mathrm{P}$ homeostasis is not known, it is up-regulated under phosphate starvation in the roots of white lupin and Arabidopsis $[35,36]$. In Arabidopsis targets of miRNA166 are the TFs PHB and PHV, for which white lupin homologs show variation in transcript abundance across the cluster root tissues, and these form a regulatory circuit to control cell fate in the root meristem [62]. The targets of miRNA393 are several F-Box proteins of the TIR1 subfamily (TIR1, AFB1/ $2 / 3$ ) of auxin receptors and a TF of the bHLH family
(bHLH77). In agreement with this it has been shown that the modulation of auxin sensitivity under phosphate deficiency, responsible for the alteration in lateral root patterning, is dependent on TIR1 [19]. With auxin being the major signalling molecule controlling root development it is therefore likely that miRNA393 and TIR1 play a role in the auxin-mediated regulation of cluster root formation. For the other identified miRNAs transcript abundance was similar across the analysed root tissues. This is in agreement with findings that only a few pri-miRNA show an altered expression under abiotic stresses although the abundance of the corresponding mature miRNA changes. This discrepancy has been attributed to differential turnover of the mature miRNA and the processing efficiency of the pri-miRNAs [71,72].

\section{Conclusions}

In conclusion, cluster root formation is a complex process that integrates spatiotemporally developmental events from the sensing of nutrient limitation, especially phosphorus, to the formation of a morphologically highly organised structure. We have identified an intricate network of signalling components and accompanying changes in gene expression controlling the formation of cluster roots. This also allows the plant to acclimate to Pi limitation in the different developmental stages of the cluster root. A better understanding of such adaptive mechanisms will help in improving plants by increasing their phosphate acquisition efficiency.

\section{Methods}

Plant material

Plants were grown and tissue harvested identical to FlorezSarasa et al. [73]. Briefly, seeds of white lupin (Lupinus albus L. cv. Kiev mutant) were sown and germinated in pots filled with washed sand. Seedlings were carefully removed and the roots gently washed free of sand. Sevenday-old seedlings of uniform size were then transferred to a solution culture system each holding $20 \mathrm{~L}$ of continuously aerated nutrient solution (pH5.5) with the following composition: $5 \mathrm{mM} \mathrm{KNO}, 1.5 \mathrm{mM} \mathrm{Ca}\left(\mathrm{NO}_{3}\right)_{2}, 1 \mathrm{mM}$ $\mathrm{MgSO}_{4}, 23.1 \mu \mathrm{M} \mathrm{H}_{3} \mathrm{BO}_{3}, 0.38 \mu \mathrm{M} \mathrm{ZnSO}_{4}, 0.29 \mu \mathrm{M}$ $\mathrm{Na}_{2} \mathrm{MoO}_{4}, 0.16 \mu \mathrm{M} \mathrm{CuSO}_{4}, 4.85 \mu \mathrm{M} \mathrm{MnSO}_{4}, 19.14 \mu \mathrm{M}$ Fe-EDDHA and for $\mathrm{P}$ sufficient plants supplemented with $1 \mathrm{mM} \mathrm{NH}_{4} \mathrm{H}_{2} \mathrm{PO}_{4}$ for the $+\mathrm{P}$ treatment. The entire nutrient solution was fully changed twice a week and $\mathrm{pH}$ was checked daily and readjusted back to around pH5.5. The plants were grown in a temperature-controlled glasshouse, with tubs half-immersed in a basin maintained at $19-22^{\circ}$ $\mathrm{C}$. The tubs were randomized and rotated weekly. Roots at the 6 to 8-trifoliolate stage were excised as root tips (TR, $1.5 \mathrm{~cm}$ of the root apex) and mature root (MR, $1.5 \mathrm{~cm}$ from the root base) for P sufficient plants and root tip (TCR, $1.5 \mathrm{~cm}$ of the root apex, free of visible laterals), 
immature cluster root (ICR, $1 \mathrm{~cm}$ following the TCR with developing laterals) and mature cluster root (MCR, $1 \mathrm{~cm}$ with only mature laterals) for P-deficient plants identical to Florez-Sarasa et al. [73]. The experiment was performed in three independent biological replicates.

\section{RNA extraction and next generation sequencing}

The total RNA from the roots tissues was extracted using the Spectrum Plant Total RNA kit (SigmaAldrich, Castle Hill, Australia) according to the manufacturer's instructions. The integrity and quality of the total RNA was checked using NanoDrop 1000 Spectrophotometer and formaldehyde agarose gel electrophoresis. RNA was only used when the Abs260 nm/Abs280 $\mathrm{nm}$ ratio was $>1.8$.

For RNA-seq library synthesis, $1 \mu \mathrm{g}$ of total RNA was first depleted of rRNA using the Ribo-Zero rRNA Magnetic Kit (Plant Seed/Root kit, Epicentre, Madison, USA). Sequencing libraries were generated using the TruSeq RNA Sample Prep Kit (Illumina, Scoresby, Australia). Sequencing was then performed on a Hiseq 1000 as a $2 \times 101 \mathrm{bp}$ paired-end run according to manufacturer's instructions (Illumina, Scoresby, Australia). RNA-seq read data were deposited to the NCBI Sequence Read Archive (NCBI SRA) under accession number SRA145661.

De novo transcriptome assembly and functional classification For the assembly of RNA-seq reads into contigs the Velvet/Oases pipeline was applied [28]. In total 133,045,174 paired-end reads of the three replicates from the five tissues samples were obtained. These reads were of high quality with a Phred score of above +30 and a minimal length of 90 bases. For optimisation of Velvet assembly parameters a Perl-based script was used (VelvetOptimiser Version 2.2.5, Victorian Bioinformatics Consortium, Monash University) which identified an optimal k-mer length of 67 for the assembly. To combine the obtained contigs with LAGI01 [26], the two assemblies were merged using CD-HIT-EST [74]. For annotation, homology searches were performed with Blast2go [75] against the NCBI database using the blastx algorithm with a cut-off of $\mathrm{E}<10^{-15}$ and targeted searches using the BLAT algorithm [76] against the soybean (Gmax_189) and Arabidopsis (TAIR10) transcriptome releases. Finally, contigs below 200 bp in length, with no assigned annotation or identified as contamination were removed from the assembly to yield the Lupinus albus Gene Index Version 2 (LAGI02) with a total of 65,097 contigs (sequences supplied in Additional files 2 and 3). Because the highest similarity in homology searches was observed between the soybean and lupin transcriptomes, GO terms for LAGI02 contigs were assigned based on the Gmax_189 genome release.

\section{Gene expression and data analysis}

For gene expression analysis RNA-seq reads obtained for the three biological replicates for each tissue were mapped to the LAGI02 transcriptome using the Bowtie tool [77]. For quantification of transcript abundances and identification of significant changes in transcript expression the Cuffdiff tool with a upper quartile normalisation and multi read correction was applied to obtain FPKM values [78]. Hierarchical clustering was performed using the Manhattan distance matrix of the heatmap.2 function in the gplots package of the $\mathrm{R}$ environment. Over-representation of GO terms within gene clusters was identified with the BiNGO plugin for Cytoscape using a hypergeometric test after Benjamini and Hochberg FDR correction with a significance level of $\mathrm{p}<0.01$ [79]. For predication of miRNA hairpin structures the Vienna RNA websuite was used [80].

\section{Availability of supporting data}

All sequences for LAGI02 contigs and their annotation are available as additional files (Additional files 1, 2 and 3). RNA-seq read data has been deposited in the NCBI SRA database under accession SRA145672.

\section{Additional files}

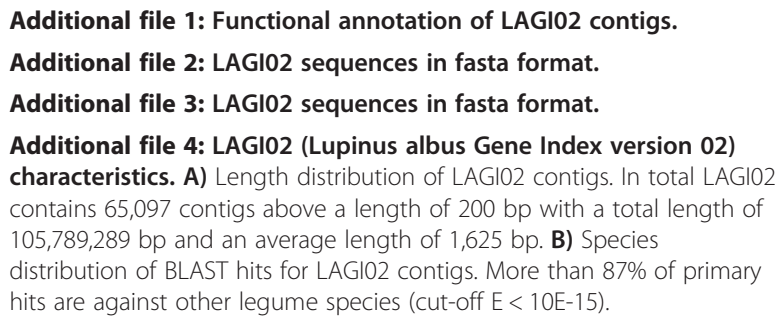

Additional file 5: Classification of LAGI02 contigs to gene ontology (GO) terms. LAGI02 contigs were assigned to plant GOslim terms within each of the three main ontologies biological process, cellular component and molecular function. For comparison the distribution of GOslim terms for LAGI02 and the soybean (genome release Gmax_189) classification are shown. Numbers give percentages of each GOslim term within main ontologies.

Additional file 6: MapMan bin classification of LAGI02 contigs. LAGI02 contigs were assigned to MapMan bins using the Mercator pipeline (http://mapman.gabipd.org). Shown is a comparison of MapMan bin classifications of the LAGI02 annotation with those for soybean and Arabidopsis based on the Gmax_189 and TAIR10 genome releases, respectively, downloaded from the MapMan website.

Additional file 7: FPKM values after expression quantification of LAGI02 contigs.

Additional file 8: Exemplary read visualisation for LAGI02 contigs differentially expressed across tissues. Three examples of genes differentially expressed across tissues. Shown are read mappings to the LAGI02 transcriptome assembly visualised using the IGV browser. MLS has high read numbers in the MCR and ICR, PAP10 in all P-deficient tissues ( $M C R, I C R, T C R)$ and $\mathrm{PHO} 2$ shows higher transcript abundance in the P-sufficient tissues (MR, TR), likely because of miRNA399 induced degradation in the P-deficient tissues. Abbreviations for tissue samples: +P) MR, mature root; TR: tip of root; -P) MCR, mature cluster root; ICR, immature cluster root; TCR, tip of cluster root Abbreviations for genes: MLS, MALATE SYNTHASE; PAP10, PURPLE ACID PHOSPHATASE10; PHO2, PHOSPHATE2. 
Additional file 9: MapMan visualisation of differentially gene expression in root tips and mature parts of P-sufficient and -deficient roots. Known P starvation responsive genes show a similar differential expression in comparisons of the mature root tissues and root tips of plants grown under $-\mathrm{P}$ and $+\mathrm{P}$ conditions, i.e. MCR vs. MR and TCR vs. TR. Shown are P-transporters, genes involved in phosphate uptake, in the regulation of $\mathrm{P}$ homeostasis and genes related to metabolic reactions in the acclimation to $P$ limitation. Shown are log2 values for FPKM ratios. Abbreviations: PHT, PHOSPHATE TRANSPORTER; SPX, SPX-domain containing; TF, transcription factors; PHO1, PHOSPHATE1; PAP, PURPLE ACID PHOSPHATASE.

Additional file 10: Differential expression of genes in the mature part and the root tip of the cluster root involved in membrane transport. MapMan visualisation of differential expression for genes involved in the transport of ions and other solutes across various cellular membranes. Shown are $\log _{2}$ values for the FPKM ratios of MCR Vs. TCR.

Additional file 11: Enriched GO terms in Clusters 1 and Clusters 2/3 for contigs differentially expressed across cluster root tissues.

\section{Additional file 12: Secondary structures for white lupin and}

soybean pre-miRNA hairpins. Shown are the hairpin structures of white lupin pre-miRNA and their corresponding homologs in soybean with sequences of mature miRNAs in red. Hairpin structures were predicted using the Vienna websuite (http://rna.tbi.univie.ac.at/) and compared to predictions for homologs in miRBase (http://www.mirbase.org/).

\section{Competing interests}

The authors declare that they have no competing interests.

\section{Authors' contributions}

DS carried out the RNA-seq experiments, participated in the bioinformatic analyses and the drafting of the paper. HS and JW conceived of the study, participated in its design and helped to draft the manuscript. OB performed the bioinformatic analyses and drafted the manuscript. All authors read and approved the final manuscript.

\section{Acknowledgements}

We would like to thank Xing Wang (School of Plant Biology, The University of Western Australia) for technical assistance with plant growth and for tissue collection and Hans Lambers (School of Plant Biology, The University of Western Australia) for critical comments on the manuscript. This work was supported by the Australian Research Council (FS10010002; D.S.), (CEO561495, CE140100008; J.W.), contributions by the Australian Research Council and the Department of Agriculture and Food WA (LP0990355; O.B.), the National Science Foundation of China $(31172024,31201675$; H.S.) and the Ministry of Science and Technology of China (2010DFA31080, 2011CB100303; H.S.).

\section{Author details}

${ }^{1}$ Australian Research Council Centre of Excellence in Plant Energy Biology, University of Western Australia, Crawley, WA 6009, Australia. ${ }^{2}$ State Key Laboratory of Plant Physiology and Biochemistry, College of Life Sciences, Zhejiang University, Hangzhou 310058, China. ${ }^{3}$ Joint Research Laboratory in Genomics and Nutriomics, College of Life Sciences, Zhejiang University, Hangzhou 310058, China. ${ }^{4}$ Department of Botany, School of Life Science, La Trobe University, Bundoora, Victoria 3086, Australia. ${ }^{5}$ School of Plant Biology, University of Western Australia, Crawley, WA 6009, Australia.

Received: 14 January 2014 Accepted: 18 March 2014

Published: 25 March 2014

\section{References}

1. Gerke J: Phosphate, aluminum and iron in the soil solution of 3 different soils in relation to varying concentrations of citric acid. Z Pflanz Bodenkunde 1992, 155:339-343.

2. Scholz RW, Wellmer FW: Approaching a dynamic view on the availability of mineral resources: what we may learn from the case of phosphorus? Global Environ Change-Human and Policy Dimensions 2013, 23:11-27.

3. Chiou TJ, Lin SI: Signaling network in sensing phosphate availability in plants. Annu Rev Plant Biol 2011, 62:185-206.
4. Essigmann B, Guler S, Narang RA, Linke D, Benning C: Phosphate availability affects the thylakoid lipid composition and the expression of SQD1, a gene required for sulfolipid biosynthesis in Arabidopsis thaliana. Proc Natl Acad Sci U S A 1998, 95:1950-1955.

5. Secco D, Wang C, Arpat BA, Wang Z, Poirier Y, Tyerman SD, Wu P, Shou H, Whelan J: The emerging importance of the SPX domain-containing proteins in phosphate homeostasis. New Phytol 2012, 193:842-851.

6. Bari R, Datt Pant B, Stitt M, Scheible WR: PHO2, microRNA399, and PHR1 define a phosphate-signaling pathway in plants. Plant Physio/ 2006, 141:988-999.

7. Aung K, Lin SI, Wu CC, Huang YT, Su CL, Chiou TJ: pho2, a phosphate overaccumulator, is caused by a nonsense mutation in a microRNA399 target gene. Plant Physiol 2006, 141:1000-1011.

8. Liu TY, Huang TK, Tseng CY, Lai YS, Lin SI, Lin WY, Chen JW, Chiou TJ: $\mathrm{PHO} 2$-dependent degradation of $\mathrm{PHO} 1$ modulates phosphate homeostasis in Arabidopsis. Plant Cell 2012, 24:2168-2183.

9. Huang TK, Han CL, Lin SI, Chen YJ, Tsai YC, Chen YR, Chen JW, Lin WY, Chen PM, Liu TY, Chen YS, Sun CM, Chiou TJ: Identification of downstream components of ubiquitin-conjugating enzyme PHOSPHATE2 by quantitative membrane proteomics in arabidopsis roots. Plant Cell 2013, 25:4044-4066.

10. Peret B, Clement M, Nussaume L, Desnos T: Root developmental adaptation to phosphate starvation: better safe than sorry. Trends Plant Sci 2011, 16:442-450.

11. Lambers H, Shane MW, Cramer MD, Pearse SJ, Veneklaas EJ: Root structure and functioning for efficient acquisition of phosphorus: matching morphological and physiological traits. Ann Bot 2006, 98:693-713.

12. Neumann G, Martinoia E: Cluster roots-an underground adaptation for survival in extreme environments. Trends Plant Sci 2002, 7:162-167.

13. Cheng L, Bucciarelli B, Shen J, Allan D, Vance CP: Update on lupin cluster roots: update on white lupin cluster root acclimation to phosphorus deficiency. Plant Physiol 2011, 156:1025-1032.

14. Shane MW, De Vos M, De Roock S, Lambers H: Shoot P status regulates cluster-root growth and citrate exudation in Lupinus albus grown with a divided root system. Plant Cell Environ 2003, 26:265-273.

15. Shu LZ, Shen JB, Rengel Z, Tang CX, Zhang FS: Cluster root formation by Lupinus albus is modified by stratified application of phosphorus in a split-root system. J Plant Nutr 2007, 30:271-288.

16. Watt $M$, Evans JR: Linking development and determinacy with organic acid efflux from proteoid roots of white lupin grown with low phosphorus and ambient or elevated atmospheric $\mathrm{CO} 2$ concentration. Plant Physiol 1999, 120:705-716.

17. Lavenus J, Goh T, Roberts I, Guyomarc'h S, Lucas M, De Smet I, Fukaki H, Beeckman T, Bennett M, Laplaze L: Lateral root development in arabidopsis: fifty shades of auxin. Trends Plant Sci 2013, 18:450-458.

18. Lopez-Bucio J, Hernandez-Abreu E, Sanchez-Calderon L, Nieto-Jacobo MF, Simpson J, Herrera-Estrella L: Phosphate availability alters architecture and causes changes in hormone sensitivity in the arabidopsis root system. Plant Physiol 2002, 129:244-256.

19. Perez-Torres CA, Lopez-Bucio J, Cruz-Ramirez A, Ibarra-Laclette E, Dharmasiri S, Estelle M, Herrera-Estrella L: Phosphate availability alters lateral root development in arabidopsis by modulating auxin sensitivity via a mechanism involving the TIR1 auxin receptor. Plant Cell 2008, 20:3258-3272.

20. Nacry P, Canivenc G, Muller B, Azmi A, Van Onckelen H, Rossignol M, Doumas $P$ : A role for auxin redistribution in the responses of the root system architecture to phosphate starvation in arabidopsis. Plant Physiol 2005, 138:2061-2074.

21. Laplaze L, Benkova E, Casimiro I, Maes L, Vanneste S, Swarup R, Weijers D Calvo V, Parizot B, Herrera-Rodriguez MB, Offringa R, Graham N, Doumas P, Friml J, Bogusz D, Beeckman T, Bennett M: Cytokinins act directly on lateral root founder cells to inhibit root initiation. Plant Cell 2007, 19:3889-3900.

22. Bielach A, Podlesakova K, Marhavy P, Duclercq J, Cuesta C, Muller B, Grunewald W, Tarkowski P, Benkova E: Spatiotemporal regulation of lateral root organogenesis in arabidopsis by cytokinin. Plant Cell 2012, 24:3967-3981.

23. Dello loio R, Galinha C, Fletcher AG, Grigg SP, Molnar A, Willemsen $V$, Scheres B, Sabatini S, Baulcombe D, Maini PK, Tsiantis M: A PHABULOSA/ cytokinin feedback loop controls root growth in arabidopsis. Curr Biol 2012, 22:1699-1704. 
24. Gilbert GA, Knight JD, Vance CP, Allan DL: Proteoid root development of phosphorus deficient lupin is mimicked by auxin and phosphonate. Ann Bot 2000, 85:921-928.

25. Meng ZB, You XD, Suo D, Chen YL, Tang C, Yang JL, Zheng SJ: Root-derived auxin contributes to the phosphorus-deficiency-induced cluster-root formation in white lupin (Lupinus albus). Physiol Plant 2013, 148:481-489.

26. O'Rourke JA, Yang SS, Miller SS, Bucciarelli B, Liu J, Rydeen A, Bozsoki Z, Uhde-Stone C, Tu ZJ, Allan D, Gronwald JW, Vance CP: An RNA-Seq transcriptome analysis of orthophosphate-deficient white lupin reveals novel insights into phosphorus acclimation in plants. Plant Physiol 2013, 161:705-724.

27. Neumann G, Massonneau A, Langlade N, Dinkelaker B, Hengeler C, Romheld V, Martinoia E: Physiological aspects of cluster root function and development in phosphorus-deficient white lupin (Lupinus albus L.). Ann Bot 2000, 85:909-919.

28. Schulz MH, Zerbino DR, Vingron M, Birney E: Oases: robust de novo RNA-seq assembly across the dynamic range of expression levels. Bioinformatics 2012, 28:1086-1092.

29. Thimm O, Blasing O, Gibon Y, Nagel A, Meyer S, Kruger P, Selbig J, Muller LA Rhee SY, Stitt M: mapman: a user-driven tool to display genomics data sets onto diagrams of metabolic pathways and other biological processes. Plant J 2004, 37:914-939.

30. Juszczuk I, Malusà E, Rychter AM: Oxidative stress during phosphate deficiency in roots of bean plants (Phaseolus vulgaris L.). J Plant Physiol 2001, 158:1299-1305

31. Torabi S, Wissuwa M, Heidari M, Naghavi MR, Gilany K, Hajirezaei MR, Omidi M, Yazdi-Samadi B, Ismail AM, Salekdeh GH: A comparative proteome approach to decipher the mechanism of rice adaptation to phosphorous deficiency. Proteomics 2009, 9:159-170

32. Tsukagoshi H, Busch W, Benfey PN: Transcriptional regulation of ROS controls transition from proliferation to differentiation in the root. Cell 2010, 143:606-616.

33. Chang L, Ramireddy E, Schmulling T: Lateral root formation and growth of Arabidopsis is redundantly regulated by cytokinin metabolism and signalling genes. J Exp Bot 2013, 64:5021-5033.

34. Franco-Zorrilla JM, Martin AC, Leyva A, Paz-Ares J: Interaction between phosphate-starvation, sugar, and cytokinin signaling in arabidopsis and the roles of cytokinin receptors CRE1/AHK4 and AHK3. Plant Physiol 2005, 138:847-857.

35. Zhu YY, Zeng HQ, Dong CX, Yin XM, Shen QR, Yang ZM: microRNA expression profiles associated with phosphorus deficiency in white lupin (Lupinus albus L.). Plant Sci 2010, 178:23-29.

36. Hsieh LC, Lin SI, Shih AC, Chen JW, Lin WY, Tseng CY, Li WH, Chiou TJ: Uncovering small RNA-mediated responses to phosphate-deficiency in arabidopsis by deep sequencing. Plant Physiol 2009, 151:2120-2132.

37. Misson J, Raghothama KG, Jain A, Jouhet J, Block MA, Bligny R, Ortet P, Creff A, Somerville S, Rolland N, Doumas P, Nacry P, Herrerra-Estrella L, Nussaume L, Thibaud MC: A genome-wide transcriptional analysis using Arabidopsis thaliana Affymetrix gene chips determined plant responses to phosphate deprivation. Proc Natl Acad Sci U S A 2005, 102:11934-11939.

38. Morcuende R, Bari R, Gibon Y, Zheng W, Pant BD, Blasing O, Usadel B, Czechowski T, Udvardi MK, Stitt M, Scheible WR: Genome-wide reprogramming of metabolism and regulatory networks of Arabidopsis in response to phosphorus. Plant Cell and Environ 2007, 30:85-112.

39. Wu P, Ma L, Hou X, Wang M, Wu Y, Liu F, Deng XW: Phosphate starvation triggers distinct alterations of genome expression in arabidopsis roots and leaves. Plant Physiol 2003, 132:1260-1271.

40. Zheng L, Huang F, Narsai R, Wu J, Giraud E, He F, Cheng L, Wang F, Wu P, Whelan J, Shou H: Physiological and transcriptome analysis of iron and phosphorus interaction in rice seedlings. Plant Physiol 2009, 151:262-274.

41. Wang S, Zhang S, Sun C, Xu Y, Chen Y, Yu C, Qian Q, Jiang DA, Qi Y: Auxin response factor (OsARF12), a novel regulator for phosphate homeostasis in rice (Oryza sativa). New Phytol 2014, 201:91-103.

42. Secco D, Jabnoune M, Walker $H$, Shou $H$, Wu P, Poirier $Y$, Whelan J: Spatio-temporal transcript profiling of rice roots and shoots in response to phosphate starvation and recovery. Plant Cell 2013, 25:4285-4304.

43. Massonneau A, Langlade N, Leon S, Smutny J, Vogt E, Neumann G, Martinoia E: Metabolic changes associated with cluster root development in white lupin (Lupinus albus L.): relationship between organic acid excretion, sucrose metabolism and energy status. Planta 2001, 213:534-542.
44. Linkohr BI, Williamson LC, Fitter AH, Leyser HM: Nitrate and phosphate availability and distribution have different effects on root system architecture of arabidopsis. Plant J 2002, 29:751-760.

45. Rouached $H$, Secco D, Arpat B, Poirier $Y$ : The transcription factor PHR plays a key role in the regulation of sulfate shoot-to-root flux upon phosphate starvation in Arabidopsis. BMC Plant Biol 2011, 11:19.

46. Kant S, Peng M, Rothstein SJ: Genetic regulation by NLA and MicroRNA827 for maintaining nitrate-dependent phosphate homeostasis in arabidopsis. PLOS Genet 2011, 7:e1002021

47. Ticconi CA, Lucero RD, Sakhonwasee S, Adamson AW, Creff A, Nussaume L, Desnos T, Abel S: ER-resident proteins PDR2 and LPR1 mediate the developmental response of root meristems to phosphate availability. Proc Natl Acad Sci U S A 2009, 106:14174-14179.

48. Bournier M, Tissot N, Mari S, Boucherez J, Lacombe E, Briat J-F, Gaymard F: Arabidopsis ferritin 1 (AtFer1) gene regulation by the phosphate starvation response 1 (AtPHR1) transcription factor reveals a direct molecular link between iron and phosphate homeostasis. J Biol Chem 2013, 288:22670-22680.

49. Ward JT, Lahner B, Yakubova E, Salt DE, Raghothama KG: The effect of iron on the primary root elongation of arabidopsis during phosphate deficiency. Plant Physiol 2008, 147:1181-1191.

50. Coudert Y, Perin C, Courtois B, Khong NG, Gantet P: Genetic control of root development in rice, the model cereal. Trends Plant Sci 2010, 15:219-226.

51. Petricka JJ, Winter CM, Benfey PN: Control of arabidopsis root development. Annu Rev Plant Biol 2012, 63:563-590.

52. Blilou I, Xu J, Wildwater M, Willemsen V, Paponov I, Friml J, Heidstra R, Aida M, Palme K, Scheres B: The PIN auxin efflux facilitator network controls growth and patterning in arabidopsis roots. Nature 2005, 433:39-44.

53. Grieneisen VA, Xu J, Maree AF, Hogeweg P, Scheres B: Auxin transport is sufficient to generate a maximum and gradient guiding root growth. Nature 2007, 449:1008-1013.

54. Swarup K, Benkova E, Swarup R, Casimiro I, Peret B, Yang Y, Parry G, Nielsen E, De Smet I, Vanneste S, Levesque MP, Carrier D, James N, Calvo V, Ljung K, Kramer E, Roberts R, Graham N, Marillonnet S, Patel K, Jones JD, Taylor CG, Schachtman DP, May S, Sandberg G, Benfey P, Friml J, Kerr I, Beeckman T, Laplaze $L$, et al: The auxin influx carrier LAX3 promotes lateral root emergence. Nat Cell Biol 2008, 10:946-954.

55. Vanneste S, Friml J: Auxin: a trigger for change in plant development. Cell 2009, 136:1005-1016.

56. Zhou W, Wei L, Xu J, Zhai Q, Jiang H, Chen R, Chen Q, Sun J, Chu J, Zhu L, Liu CM, Li C: Arabidopsis Tyrosylprotein sulfotransferase acts in the auxin/PLETHORA pathway in regulating postembryonic maintenance of the root stem cell niche. Plant Cell 2010, 22:3692-3709.

57. Mashiguchi K, Tanaka K, Sakai T, Sugawara S, Kawaide H, Natsume M, Hanada A, Yaeno T, Shirasu K, Yao H, McSteen P, Zhao Y, Hayashi K, Kamiya Y, Kasahara $\mathrm{H}$ : The main auxin biosynthesis pathway in Arabidopsis. Proc Natl Acad Sci US A 2011, 108:18512-18517.

58. Qin G, Gu H, Zhao Y, Ma Z, Shi G, Yang Y, Pichersky E, Chen H, Liu M, Chen Z, Qu L: An indole-3-acetic acid carboxyl methyltransferase regulates arabidopsis leaf development. Plant Cell 2005, 17:2693-2704.

59. Ranocha P, Denance N, Vanholme R, Freydier A, Martinez Y, Hoffmann L, Kohler L, Pouzet C, Renou JP, Sundberg B, Boerjan W, Goffner D: Walls are thin 1 (WAT1), an Arabidopsis homolog of Medicago truncatula NODULIN21, is a tonoplast-localized protein required for secondary wall formation in fibers. Plant J 2010, 63:469-483.

60. Wan YL, Jasik J, Wang L, Hao HQ, Volkmann D, Menzel D, Mancuso S, Baluska F, Lin JX: The signal transducer NPH3 integrates the Phototropin1 photosensor with PIN2-based polar auxin transport in arabidopsis root phototropism. Plant Cell 2012, 24:551-565.

61. Galinha C, Hofhuis H, Luijten M, Willemsen V, Blilou I, Heidstra R, Scheres B: PLETHORA proteins as dose-dependent master regulators of arabidopsis root development. Nature 2007, 449:1053-1057.

62. Carlsbecker A, Lee JY, Roberts CJ, Dettmer J, Lehesranta S, Zhou J, Lindgren O, Moreno-Risueno MA, Vaten A, Thitamadee S, Campilho A, Sebastian J, Bowman $J$, Helariutta Y, Benfey PN: Cell signalling by microRNA165/6 directs gene dose-dependent root cell fate. Nature 2010, 465:316-321.

63. Jang G, Yi K, Pires ND, Menand B, Dolan L: RSL genes are sufficient for rhizoid system development in early diverging land plants. Development 2011, 138:2273-2281.

64. Karas B, Amyot L, Johansen C, Sato S, Tabata S, Kawaguchi M, Szczyglowski K: Conservation of lotus and arabidopsis basic helix-loop-helix proteins 
reveals new players in root hair development. Plant Physiol 2009, 151:1175-1185.

65. Menand B, Yi K, Jouannic S, Hoffmann L, Ryan E, Linstead P, Schaefer DG Dolan L: An ancient mechanism controls the development of cells with a rooting function in land plants. Science 2007, 316:1477-1480.

66. Wang P, Du Y, Zhao X, Miao Y, Song CP: The MPK6-ERF6-ROS-responsive cis-acting element7/GCC box complex modulates oxidative gene transcription and the oxidative response in arabidopsis. Plant Physiol 2013, 161:1392-1408.

67. Shin R, Berg RH, Schachtman DP: Reactive oxygen species and root hairs in arabidopsis root response to nitrogen, phosphorus and potassium deficiency. Plant Cell Physiol 2005, 46:1350-1357.

68. Khan GA, Declerck M, Sorin C, Hartmann C, Crespi M, Lelandais-Briere C: MicroRNAs as regulators of root development and architecture. Plant Mol Biol 2011, 77:47-58.

69. Pant BD, Buhtz A, Kehr J, Scheible WR: MicroRNA399 is a long-distance signal for the regulation of plant phosphate homeostasis. Plant J 2008, 53:731-738

70. Lin SI, Chiang SF, Lin WY, Chen JW, Tseng CY, Wu PC, Chiou TJ: Regulatory network of microRNA399 and PHO2 by systemic signaling. Plant Physiol 2008, 147:732-746.

71. Laubinger S, Zeller G, Henz SR, Buechel S, Sachsenberg T, Wang J-W, Rätsch G, Weigel D: Global effects of the small RNA biogenesis machinery on the arabidopsis thaliana transcriptome. Proc Natl Acad Sci U S A 2010, 107:17466-17473.

72. Reyes $\mathrm{JL}$, Chua N-H: ABA induction of miR159 controls transcript levels of two MYB factors during arabidopsis seed germination. Plant $J 2007$, 49:592-606.

73. Florez-Sarasa I, Lambers H, Wang X, Finnegan PM, Ribas-Carbo M: The alternative respiratory pathway mediates carboxylate synthesis in white lupin cluster roots under phosphorus deprivation. Plant, Cell Environ 2014, 37(4):922-928.

74. Li W, Godzik A: Cd-hit: a fast program for clustering and comparing large sets of protein or nucleotide sequences. Bioinformatics 2006, 22:1658-1659.

75. Conesa A, Gotz S, Garcia-Gomez JM, Terol J, Talon M, Robles M: Blast2GO: a universal tool for annotation, visualization and analysis in functional genomics research. Bioinformatics 2005, 21:3674-3676.

76. Kent WJ: BLAT-the BLAST-like alignment tool. Genome Res 2002, 12:656-664.

77. Langmead B, Trapnell C, Pop M, Salzberg SL: Ultrafast and memory-efficient alignment of short DNA sequences to the human genome. Genome Biol 2009, 10:R25.

78. Trapnell C, Williams BA, Pertea G, Mortazavi A, Kwan G, van Baren MJ, Salzberg SL, Wold BJ, Pachter L: Transcript assembly and quantification by RNA-Seq reveals unannotated transcripts and isoform switching during cell differentiation. Nat Biotechnol 2010, 28:511-515.

79. Maere S, Heymans K, Kuiper M: BiNGO: a cytoscape plugin to assess overrepresentation of gene ontology categories in biological networks. Bioinformatics 2005, 21:3448-3449.

80. Gruber AR, Lorenz R, Bernhart SH, Neubock R, Hofacker IL: The vienna RNA websuite. Nucleic Acids Res 2008, 36:W70-74.

doi:10.1186/1471-2164-15-230

Cite this article as: Secco et al:: RNA-seq analysis identifies an intricate regulatory network controlling cluster root development in white lupin. BMC Genomics 2014 15:230.

\section{Submit your next manuscript to BioMed Central and take full advantage of:}

- Convenient online submission

- Thorough peer review

- No space constraints or color figure charges

- Immediate publication on acceptance

- Inclusion in PubMed, CAS, Scopus and Google Scholar

- Research which is freely available for redistribution

Submit your manuscript at www.biomedcentral.com/submit
Ciomed Central 